\title{
思
}

LINGUACULTURE 2,2014

\section{S. LEWIS AND THE ART OF READING: THE USES OF SCHOLARSHIP AND THE PLEASURES OF THE TEXT}

\author{
TILL KINZEL \\ Technical University of Berlin
}

\begin{abstract}
C. S. Lewis was one of the major scholars of literature in the $20^{\text {th }}$ century. His contribution to the art of reading deserves a re-consideration and is therefore reconstructed and analysed in this paper. Topcis that are highlighted in this connection are the types of literary scholarship most useful to a proper understanding of old texts, the types of readers that exist, the controversies in which Lewis engaged concerning the interpretation of Milton, the importance of philological knowledge for literary scholars as well as the pitfalls of literary criticism. In many respects, C. S. Lewis is at odds with currently fashionable approaches to literature-and thus provides a welcome challenge to dominant paradigms of reading texts.
\end{abstract}

Keywords: pleasures of the text, hermeneutics, literary theory, literary scholarship, literary criticism, types of readers, storytelling, Milton criticism

Why one should read literature is not obvious to everyone. What are the specific pleasures of literature that should lead one to prefer reading it to other leisure activities? In order to understand what functions literature can fulfil, I propose to review C. S. Lewis' approach to reading in this paper. Lewis' outstanding contribution to $20^{\text {th }}$ century literary scholarship is often somewhat neglected, at least compared with the enormous influence some of his more popular writings have achieved. This does not mean, of course, that his critical writings have been ignored (see e.g. Mason 1971; Kranz 1983; Christopher 1987, 22-50; MacSwain/Ward 2010). But there can be no doubt that for most readers Lewis is the author of famous novels, particularly the Narnia tales, as well as popular apologetic writings such as Mere Christianity or The Screwtape Letters.

In order to redress this rather deplorable situation, I propose to take a closer look at some aspects of Lewis' literary scholarship. I want to do this with a view to what may still be of interest in these writings more than 50 years after Lewis died. In standard text books dealing with literary theory, Lewis hardly gets a mention, and his approach to reading books is distinctly at odds with what can 
count as politically and/or theoretically correct ways of reading. Those who like to read his fiction or his apologetics may well profit from extending their reading to Lewis' other writings that one needs to know if one wants to get a complete picture of the man.

Perhaps it is precisely the marginal position accorded to Lewis in text books on literary studies that should make us want to take another look at what Lewis wrote about literature-and about how literature should be read. For it is one of Lewis' achievements to have proffered a tentative understanding of the act of reading and its importance, even though on a less intimidating theoretical level than Wolfgang Iser, e.g. (see De Bruyn 2012). Understanding literary theory can profit very much from studying closely the work of individual literary critics and theorists. For the very structure and practice of literary criticism and literary scholarship is closely linked to the kind of personality that takes up these activities. Literary scholars would misinterpret their own activity, if they regarded it as a purely objective scholarly work. For the way in which works of literature are studied is tied to education, or "Bildung." This means that a personal approach to works of art/literature is inevitable, although this does not preclude the recognition of some objective quality in literary scholarship.

To study the history of literary scholarship, one has to take a closer look at institutional frameworks such as schools, colleges and universities. But it is equally important to consider individual critics and the schools of criticism they may have founded or encouraged. Tying styles of literary criticism to personality may thus entail a certain loss of objectivity, but this is merely the necessary consequence of the fact that literary scholarship is not a science but rather an art.

C. S. Lewis is a test case for this understanding of the nature of literary scholarship (see also Fleming 2010). For despite the radical changes in literary studies since Lewis' death, it seems worth pursuing in more detail how Lewis conceived of this subject. Especially in the wake of a somewhat mind-boggling theoretical overkill in literary studies, Lewis' approach provides a healthy reminder of essentials that literary critics should keep in mind.

Lewis' personality surely contributed to the immense popularity of his lectures at Oxford, as Northrop Frye, later a famous scholar of literature himself, reports. Frye noted that Lewis's engaging style was an exception amid generally bad standards of teaching. This kind of teaching was particularly evident in those cases where lecturers lost themselves in endless discussions about details that were not linked to an overall picture of the topic (Ayre 1989, 131). Lewis' was not only a competent lecturer, but also a renowned author. As Kingsley Amis noted, C. S. Lewis' The Allegory of Love (1936) was one of two works of literary criticism that everyone had to read - the other being William Empson's Seven Types of Ambiguity (Leader 2007, 191). Empson and Lewis also presented opposing interpretations of Milton, Empson being a critic with a very different outlook in terms of ideology and religion (Haffenden 3). Lewis' book on the 
allegory of love was influential in a number of ways, not the least because many writers on the topics Lewis addresses in this book felt compelled to confront his arguments. Even if no extended discussion of Lewis can be found, he can still be considered a standard reference study that anyone interested in writers from Chaucer to Spenser would do well not to ignore (cf. also Kinzel 2012, 117-132).

In the present paper I will not discuss all of Lewis' works of literary scholarship. Not only would I have to discuss a large number of scholarly articles and essays that need to be considered in conjunction with the texts they discuss; one would also have to take into consideration his numerous reviews that provide some evidence of how Lewis read texts (see Lewis 2013). A number of scholars have discussed Lewis' interpretations of canonical authors such as Chaucer, Spenser or Milton, so there is no need to delve into this topic here (cf. Adey 1998, 68-84). To give just one example and to point to just a few contexts of interest, let me adduce a few remarks on Lewis and Milton. Lewis' introductory book on Milton's Paradise Lost was without doubt one of the most influential works of literary criticism in the $20^{\text {th }}$ century. An eminent critic like William Empson felt he had to engage Lewis' views in his book Milton's God. Further evidence of the influence exerted by Lewis' Preface to Paradise Lost is the criticism levelled against the book by literary scholars such as Harold Bloom and Stanley Fish. Both deplored the book's success, as the following words of Harold Bloom show:

Academic criticism of literature in our time became almost an affair of church wardens; too many students for instance learned to read Milton by the dubious light of C. S. Lewis's Preface to Paradise Lost, in which the major Protestant poem in the language becomes and Anglo-Catholic document. (Bloom 1971, XVIII).

For Fish, on the other hand, Lewis belongs to one of two traditions that have led Milton scholarship off track. According to Fish, Lewis belongs to the tradition that finds a simple moral in Milton's epic poem, a moral that condemns rebellion against God as evil. The other tradition, reaching from Blake to Empson considers Milton as a poet "of the Devil's party without knowing it" (Fish 1998, IX). Lewis' refusal to consider these counter-intentional interpretive options within the framework of his own image of Milton, Manlove $(1987,3)$ claims, leads to the simplification of the poet's work as a result of the desire "to provide the correct Christian response." This was the case, Manlove argues, because "the spiritual core of a book for Lewis came first" (cf., however, Lewis 1981, 15-26). This may well have been a weakness of Lewis' approach to texts, evident in the lack of detailed stylistic analysis. However that may be-William Empson for his part did take Lewis' interpretation very seriously, as his regretful remarks in the preface to the second edition of his book Milton's God shows: "I greatly regret the deaths of my two chief opponents in the book, C. S. Lewis and E. M. 
W. Tillyard, who both received the first edition in a very generous-minded way" (Empson 1981, 7; McGrath 2013, 166).

One would also have to say more about Lewis' most comprehensive study, English Literature in the Sixteenth Century, Excluding Drama (still in print, though now under the title Poetry and Prose in the Sixteenth Century). This book, although no longer up to date in its bibliography, is still indispensable. Rare indeed is the work of literary scholarship that is praised in James Harner's standard reference work Literary Research Guide ( $5^{\text {th }}$ edition) as a "provocative, opinionated, sometimes brilliant work that has occasioned widespread controversy" (Harner 2008, 247). Students of English literature could do worse than to read this book which is based on as thorough and comprehensive a knowledge of sixteenth century literature as can probably be achieved in a lifetime of reading.

The most important Lewis book in connection with my topic may well be his late essay An Experiment in Criticism. In this book, Lewis distinguishes his own approach to literature from other concepts of literary criticism. In this book, Lewis presented a kind of reception theory of reading. However, this theory was not nearly "theoretical" enough for the theoretically minded climate since the 1970s in literary scholarship. It is thus hardly surprising that Lewis' kind of reception theory did not find a larger scholarly audience (cf. Adey 1998, 95). Lewis' essayistic approach could hardly appear as "scientific" as the kinds of theory on offer under the names of structuralism or semiotics. This is true even though William Gray $(2009,66)$ has pointed out the similarities of Lewis' restitution of the reader and Roland Barthes' concept of the pleasures of the text (cf. Barthes 2010, with a comprehensive commentary by Otmar Ette). Lewis was himself very much in favour of the "pleasures of the text", as he indicates in "On Science Fiction." Here, he talks of "the keen, lasting, and solemn pleasure which such stories can give" (Lewis 1982, 66). Even though there are now descriptions of acts of reading that are phenomenologically richer than Lewis' pioneering remarks, he still can be considered as an experimenter who focussed his and his readers' attention on the "act of reading". He was also methodologically minded in so far as he reflected on the difficulties of learning anything about other people's acts of reading (Lewis 1992, 104, 114).

It would be beside the point to expect systematic theories of reading and of the reader from Lewis' essay. Nevertheless, Lewis at least attempts to distinguish between different types of readers of literary texts. The most fundamental distinction he makes is the one between "the few" and "the many". This distinction is not meant as a stable dichotomy in an elitist sense. Lewis merely aims at clarifying actual differences in the manner of reading that one can observe (Lewis 1992, 2). That Lewis' is not elitist in a strict sense can be seen in his opinion that academics and literary scholars are not necessarily, or automatically, better readers than others. It is rather the case that these readers 
are particularly prone to certain kinds of misreadings. Lewis diagnoses a certain kind of "confusion of life and art" that underlies the attempt to use works of literature as sources of information, so that their authors are rather considered as teachers than as artists (Lewis 1992, 74).

It seems fair to say that some of Lewis' remarks are hardly convincing; as Lionel Adey $(1998,98-99)$ has noted, Lewis' definitions often suffer from a "lack of range, focus, and depth," which becomes particularly clear when contrasted with rival conceptions. This is definitely true, to my mind, with regard to his definition of the fantastic in literature as "any narrative that deals with impossibles and preternaturals" (Lewis 1992, 50). Adey $(1998,99)$ has already noted that this definition appears as superficial or lightweight compared to those offered by Tzvetan Todorov or Northrop Frye. In fact, identifying the fantastic with the impossible is unconvincing, as there are also any number of "impossible" things to be found in texts one would normally classify as realistic. It is thus hardly surprising that Lewis is mentioned a number of times in the most recent German handbook on fantastic literature, but never with regard to his definition of the fantastic (see Brittnacher/May 2013). The same observation, namely that Lewis' definition is not seriously considered, applies to Uwe Durst's standard work on fantastic literature that takes up, and corrects, Todorov's seminal study on the subject (Durst 2010). It is perhaps a consequence of the essayistic form employed by Lewis that he did not talk at length about any relevant texts, something he would have had to do if he had really wanted to address other literary scholars. As Adey $(1998,99)$ says: "To have rivaled the critical works of Todorov and Frye, it would have needed to be on the scale of Allegory of Love." As Lewis was not particularly theory-minded, one may have doubts about whether he would even have wanted to go in this direction. Most importantly, however, fellow scholars were surely not the main audience he had in mind for his reflections.

Thus, Lewis addresses himself much more to readers interested in literature than to literary scholars. This becomes clear in his emphatic instructions on how to read. He proposes that it is better to reread a given work of literature rather than read a critical study about it. Of course, advice like that is itself somehow part of secondary literature. But in general, Lewis' point is important, as it emphasises the benefits of a thorough knowledge of the primary text. Lewis juxtaposes the so-called "evaluative critics" to the dry scholars, whom he calls, with a name taken from Sir Walter Scott's novels, the "Dryasdusts." It is perhaps somewhat surprising that he accords to highest rank to these dry scholars in connection with a proper understanding of literary texts. Lewis notes that he is most thankful for the work of "editors, textual critics, commentators, and lexicographers," whose work can be considered as a service to the correct way of practising literary criticism: "Find out what the author actually wrote and what the hard words meant and what the allusions were to, 
and you have done far more for me than a hundred new interpretations or assessments could ever do" (Lewis 1992, 121). Lewis poses the largely rhetorical question whether his appreciation of a scene, a chapter, a stanza, a line was ever improved by his reading of Aristotle, Dryden, Johnson, Lessing, Coleridge, Pater, Arnold or Bradley (Lewis 1992, 122).

The contextual knowledge of the literary historian is much more useful, according to Lewis, than voicing praise and blame. Instead of the evaluative critic one should rather study the author's works: "If we have to choose, it is always better to read Chaucer again than to read a new criticism of him" (Lewis 1992, 124). Whether it is in fact "always" better to reread the author rather than a critical work is open to reasonable doubt. Perhaps the cause of informed reading is best served by rejecting a rigid either-or distinction in this case. For Lewis himself would hardly have objected to studying "new criticism", some of which he wrote himself. In fact, it may very well be a critical text provides the reader with some idea of what he can find in the literary text and what he would not have noticed without the critic's help. Lewis proved by deed that he considered this a legitimate practice, as we can see when we look at the list of his publications. Why else would he have written books such as Allegory of Love and, particularly, Preface to Paradise Lost. We need to add a further observation here: Lewis explicitly remarked on the function of the latter book when he said that it was mostly meant "to hinder hindrances", i.e., to clear up difficulties of understanding (Lewis 1961, 129). Evaluative interpretations, in contrast, can be considered as further hindrances because their usefulness is not immediately clear. What counts for Lewis is less a scholarly reaction than a personal reaction to a given text, that is a "primary literary experience". It is in this context that we have to read his hopelessly futile suggestion concerning the overproduction of evaluative criticism. Lewis opposes the reading of books through the lens of other books written by "eminent critics" and comments: "I suggest that a ten or twenty years' abstinence both from the reading and from the writing of evaluative criticism might do us all a great deal of good" $(1992,129)$. This suggestion, as impracticable as it may be, still has the net value of reminding us of a key qualification for academic readers: Knowing the primary texts very well is the necessary precondition for the proper use of secondary literature. One might even go so far as to suggest that the literary writers know better than the academics what literature is all about, as the German writer Ulrich Horstmann suggests (Horstmann 2014). Lewis' definition of the literary reader as a reader who reads certain works again and again is of great pedagogical value. For it is only on re-reading texts that we will fully understand the meaning of the particular literary form, i.e., the "poetry" of a text. For Lewis, understanding a text always implies more than merely extracting information (cf. Lewis 1992, 2; 1982, 16). Narratologically speaking, the "unliterary" readers concentrate almost exclusively on the eventfulness presented in a given text, without paying 
particular attention to the form of presentation. It is for this very reason that criticism needs to focus on issues of literary form (cf. Lewis 1992, 30).

In addition, Lewis' form of literary scholarship is important for a further reason. Although in the decades since the 1960s, theoretical developments such as the "death of the author" in the senses of Barthes and Foucault contributed to the devaluation of the author function in literary scholarship, Lewis' affirmation of some notion of authorial intention is still relevant. Many literary scholars nowadays have internalized the taboo on authorial intention connected to the approach of new critics like Monroe Beardsley and William K. Wimsatt. The "intentional fallacy" highlighted by Beardsley and Wimsatt became one of the most influential figures of thought, not to say clichés, of literary scholarship, with serious consequences for the way textual analysis is practiced up to this very day (cf. Dutton 2009, 167-177). Lewis expressed the contradistinction between intentionalist and creative ways of reading by speaking of a "receiving" vs. a "using" attitude towards the text. One should note that the notion of authorial intention does not entail the thesis that the poet's or writer's work is the "expression" of their personality or of their state of mind at the time of writing. Lewis opposed such an understanding of the poet's work, as he made clear in his controversy with E. M. W. Tillyard concerning this critic's reading of Milton. Lewis' criticism of Tillyard led to an exchange between them that is documented in Personal Heresy, about which more could and should be said. But this will have to wait for another occasion, for here I want to emphasize another aspect of Lewis' kind of literary scholarship.

Lewis stressed the importance of a thorough knowledge of the meanings of those words that make up a particular text under discussion. This seems to me to be of utmost importance, even though it may appear trivial to others: A proper knowledge of the meanings of words is a key qualification of any philologist, but it is a sort of knowledge that cannot be acquired by occasionally looking up words in online dictionaries. In fact, it requires not only regular consultation of (historical) dictionaries like the OED but also the more or less constant reading of different sources and texts. Unfortunately, the flight from texts towards movies and other non-textual media in $21^{\text {st }}$ century philologies does not bode well for this kind of knowledge in Lewis' sense. For Lewis, however, it was crucial to understand the texts of the authors as they understood themselves. Even if this should prove to be insufficient for a number of reasons, it is a necessary first step that should not be ignored nor despised. Even if one wants to present an original reading that contrasts with traditional interpretations it might be useful to be clear about the differences between authorial intention and one's own interpretations. In his book Studies in Words, a text that should be on any English scholar's reading list, Lewis builds on earlier studies like William Empson's The Structure of Complex Words, with whom he was in agreement concerning the concept of "emotional language" developed by I. A. Richards 
(Lewis 1990, 314). He was as skeptical about this concept as Empson. He believed that it was not correct to consider every utterance as an instance of emotional language that really brings about emotions. For a number of so-called emotional expressions are at the same time statements of facts. Lewis clearly sticks to an understanding of language that stresses language's referential character, for it is the facts transmitted by language, not the language, that brings about certain emotions, according to Lewis (Lewis 1990, 314-315). I cannot go into this particular problem of the philosophy of language here, but let me at least note that there is ample food for thought in what Lewis says about the use of language.

In the present context I want to stress that the aim of Lewis' Studies in Words is connected to the valid idea that one should not give up on trying to determine an author's or a text's intention (cf. also Kinzel 2012, 3-16). It appears to be self-evident that one should try to make a proper understanding of certain words easier, in order to enable "a more accurate reading of old books" (Lewis 1990, 3). Lewis defends the notion that the author's intention should be valued more than the reader's subjective construction of meaning. He says: "If we read an old poem with insufficient regard for change in the overtones, and even the dictionary meanings, of words since its date-if, in fact, we are content with whatever effects the words accidentally produce in our modern minds then of course we do not read the poem the old writer intended" (Lewis 1990, 3). Lewis' preference for such a determination of the intended meaning based on the history of words is obvious, but this does not mean that he totally rejects the legitimacy of appropriating readings of texts, as one could say, employing the concepts of so-called cognitive hermeneutics (Tepe 2007). Accordingly, Lewis distinguishes between "using" and "receiving" of texts, as already mentioned (Lewis 1992, 88-89). Still, he is not very much interested in "appropriating readings" in the context of literary scholarship (although they may have their uses in other contexts, e.g., homiletic speech in religious settings). Interestingly, Lewis points out that it is exactly the most intelligent and sensitive readers that are in danger of ascribing a wrong or inappropriate meaning to certain words. For the mind of these readers, Lewis claims, is so full of possible meanings that they can easily attribute them to the author. In this way, they interpret the text so that it makes sense - some sense. Lewis distinguishes between meaning as such and meaning as it was intended by the author. It is the latter that the literary scholar is supposed to find (Lewis 1990, 5). It makes sense to read these and other remarks as a kind of criticism of deconstruction avant la lettre, in so far as deconstructive readings may generate brilliant interpretations without sufficiently checking which meanings of certain words were actually possible at the time of writing. Lewis also stresses the "insulating power of context", a feature that also marks his distance from deconstruction. The existence of this insulating power of the context ensures that, generally speaking, there is 
astonishingly little confusion concerning those meanings of words that could otherwise collide. The insulating power of the context also keeps in check what Empson has highlighted as "ambiguity". The presence of ambiguity in certain texts cannot be disputed, but it does by no means entail that ambiguous linguistic features cannot be understood as such. Likewise, the insulating power of the context also explains the co-existence of both older and newer meanings. Lewis' philological rigour thus functions as a control mechanism to delimit possible meanings. This issue is important enough with regard to the understanding of texts. But there is a further corollary, for the issue of correctly understanding some author's intention is merely a special case of the problem of understanding someone else. Literature offers the possibility of a vicarious change of perspective that can perhaps most adequately be expressed in metaphorical language: "If I can't get out of the dungeon I shall at least look out through the bars. It is better than sinking back in the straw in the darkest corner" (Lewis 1990, 101-102).

In Experiment in Criticism, Lewis mentions three different kinds of literary scholars. He offers an evaluation of their respective worth or value for the understanding and judgment of works of literature. The most important kind of scholar, as already mentioned, is the type called "Dryasdust". The second important type is the despised literary historian who offers help concerning elementary information on what exists and in which contexts certain works were written and published. Literary historians present the kind of information that one needs in order to understand the implicit presuppositions of any given text. It is exactly this attempt to provide an account of this kind of contextual knowledge that Lewis presented in some of his writings on literary history (Lewis 1992, 121). This task can be performed best when the historian is reluctant to express value judgments; he should rather stick to Matthew Arnold's famous piece of advice that literary critics should get "themselves out of the way". This type of literary critic is "concerned far more with describing books than with judging them" (Lewis 1992, 120, 122).

Lewis' approach to literature can be regarded as helpful in a number of ways. Experiment in Criticism provides interesting suggestions that aspiring literary scholars, or any reader of literature, should consider. Thus, Lewis points to the importance of recognizing the sound aspect of poetic language. He claims that "good reading is always aural as well as visual" and further notes that sound does not merely provide additional pleasure but rather belongs to the text's power of fascination. In this sense, sound also becomes part of the text's meaning (Lewis 1992, 90). Whether someone is able to appreciated the aural character of a given text is a good sign for a truly literary reception of this text (Lewis 1992, 102). Lewis can therefore be regarded as a sort of pioneer of audio-narratology, the study of the interfaces of sound and narrative. One should also note that Lewis has a very relaxed attitude towards issues of canonization 
and de-canonization. He knows about the turns of fate for certain authors or works and urges us not to pay too much attention to all this: "dethronements and restorations are almost monthly events. You can trust none of them to be permanent" (Lewis 1992, 105). This, in turn, means that every reader should engage as much as possible in the reading of both canonical and non-canonical works. One is apt to make exciting discoveries beyond the canon.

Lewis was a distinguished and accomplished practitioner of the art of narrative. In addition, he also made many comments on stories, myths and storytelling. It would be the task of another paper to look at these statements in more detail, because they provide a sort of proto-narratological conception of literature. Telling stories remains the hard core of literature even after the triumph of postmodernism with all its fragmentation etc. Surprisingly, what is narrated-the story-often survives medial transformations rather well. A closer look at Lewis' remarks e.g. in his essay "On Stories" might yield further insights into Lewis' understanding of narrative, its structures and functions.

One last—and particularly topical-remark is in order. Lewis also vehemently rejects another group of literary critics that he labels the "Vigilant school of critics". In our times we would perhaps call them critics in the service of political correctness, a sort of critics who are more concerned about morality than aesthetic value. These critics, Lewis maintains, look on literary criticism as a kind of social and ethical hygiene. This means that they apply non-literary criteria to works of literature-and they do this with the best intentions of detecting, and checking, a great evil. The potentially totalitarian touch of this kind of literary criticism is connected to the fact that "their conception of what is good in literature makes a seamless whole with their total conception of the good life". It is for this reason that there cannot be, for these critics, a separate realm of aesthetic experiences (Lewis 1992, 125-126). Lewis' rejection of this approach is important, because the vigilant reading of literature is a temptation that is intrinsic to literary criticism. Lewis' critique of morally limiting interpretations for reasons of social and ethical hygiene is complement by his recognition of the fundamental incompleteness of all interpretation. This openness and incompletability of interpretation means that there cannot be a universal hermeneutics. Instead there can only be the attempt to make concrete experiences of reading that are informed by knowledge about literary history and genres. Lewis' contribution to this kind of knowledge is considerable and still very much worth studying. Finally, his approach to the study of literature is genuinely inspiring, because Lewis opens up a space for the pleasures of the text. A proper understanding of the link between these two-knowledge and pleasure-would lead to a consideration of the limits of the attempt to turn literary studies into some kind of science. 


\section{Works cited}

Adey, Lionel. C.S. Lewis: Writer, Dreamer and Mentor. Grand Rapids: Eerdmans, 1998. Print.

Ayre, John. Northrop Frye: A Biography. Toronto: Random House, 1989. Print.

Barthes, Roland. Die Lust am Text. Kommentar von Otmar Ette. Berlin: Suhrkamp, 2010. Print.

Bloom, Harold. The Visionary Company: A Reading of English Romantic Poetry. Revised and enlarged edition. Ithaca: Cornell University Press, 1971. Print.

Brittnacher, Hans Richard/May Markus (eds.): Phantastik. Ein interdisziplinäres

Handbuch. Stuttgart/Weimar 2013. Print.

Carpenter, Humphrey. The Inklings: C.S Lewis, J.R.R. Tolkien, Charles Williams and their Friends. London: HarperCollins, 2006. Print.

Christopher, Joe R. C.S. Lewis. Boston: Twayne, 1987. Print.

De Bruyn, Ben. Wolfgang Iser: A Companion. Berlin: De Gruyter, 2012. Print.

Durst, Uwe. Theorie der phantastischen Literatur. $2^{\text {nd }}$ edition. Berlin 2010. Print.

Dutton, Denis. The Art Instinct: Beauty, Pleasure, and Human Evolution. New York: Bloomsbury Press, 2009. Print.

Empson, William. Milton's God. Cambridge: Cambridge University Press, 1981. Print.

Fish, Stanley. Surprised by Sin: The Reader in Paradise Lost. Second edition. Cambridge: Harvard University Press, 1998. Print.

Fleming, John V. „Literary Critic“. The Cambridge Companion to C.S. Lewis. Hg. von Robert MacSwain und Michael Ward. Cambridge: Cambridge University Press, 2010. 15-28. Print.

Gray, William. Death and Fantasy: Essays on Philip Pullman, C.S. Lewis, George MacDonald, and R.L. Stevenson. Cambridge Scholars Press, 2009. Print.

Haffenden, John. William Empson. Vol. I: Among the Mandarins. Oxford: Oxford University Press, 2005. Print.

Harner, James L. Literary Research Guide: An Annotated Listing of Reference Sources in English Literary Studies. Fifth Edition. New York: Modern Language Association of America, 2008. Print.

Horstmann, Ulrich. Schreibweise: Warum Schriftsteller mehr von der Literatur verstehen als ihre akademischen Bevormunder. Ein Einwurf. Würzburg: Königshausen \& Neumann, 2014.

Kinzel, Till. „C.S. Lewis als Literaturhistoriker der Liebe“. Liebe und Glück. Annäherungen mit C.S. Lewis und Josef Pieper. Hg. von Thomas Möllenbeck und Berthold Wald. Paderborn: Schöningh, 2012. 117-132. Print.

Kinzel, Till. „Wahrheit ohne Methode? Hermeneutischer Relativismus als Herausforderung", in: Philotheos. International Journal for Philosophy and Theology 12 (2012). 3-16. Print.

Kranz, Gisbert. Studien zu C.S. Lewis. Lüdenscheid: Claren, 1983. Print.

Leader, Zachary. The Life of Kingsley Amis. London: Vintage, 2007. Print.

Lewis, C.S. Christian Reflections. Ed. Walter Hooper. London: Fount, 1981. Print.

Lewis, C.S. English Literature in the Sixteenth Century, Excluding Drama. Oxford: Clarendon, 1954. Print.

Lewis, C.S. An Experiment in Criticism. Cambridge: Cambridge University Press, 1992. Print. 
Lewis, C. S. Image and Imagination: Essays and Reviews. Ed. Walter Hooper. 2013. Print.

Lewis, C.S. On Stories and Other Essays on Literature. Orlando: Harvest, 1982. Print. Lewis, C.S. A Preface to Paradise Lost. London: Oxford University Press, 1961. Print. Lewis, C.S. Studies in Medieval and Renaissance Literature. Cambridge: Cambridge University Press, 1998. Print.

Lewis. C.S. Studies in Words. Cambridge: Cambridge University Press, 1990. Print.

Lewis, C.S., and E.M.W. Tillyard. The Personal Heresy: A Controversy. Austin: Concordia University Press, 2008. Print.

McGrath, Alister. C.S. Lewis: A Life - Eccentric Genius, Reluctant Prophet. Carol Stream: Tyndale House, 2013. Print.

MacSwain, Robert, und Michael Ward (Hg.). The Cambridge Companion to C.S. Lewis. Cambridge: Cambridge University Press, 2010. Print.

Manlove, C.N. C. S. Lewis: His Literary Achievement. Basingstoke: Macmillan, 1987.

Mason, Eudo C. „C.S. Lewis“. In: Englische Dichter der Moderne: Ihr Leben und Werk. Hg von Rudolf Sühnel und Dieter Riesner. Berlin: Schmidt, 1971. 520-535. Print.

Schlaffer, Heinz. „Der Umgang mit Literatur. Diesseits und jenseits der Lektüre“, in: Poetica 1,2 (1999). 1-25. Print.

Tepe, Peter. Kognitive Hermeneutik: Textinterpretation ist als Erfahrungswissenschaft möglich. Würzburg: Königshausen \& Neumann, 2007. Print. 